\title{
Does a country's income inequality affect its citizens' quest for equality in leisure? Evidence from European men's football
}

\author{
Nicolas Scelles ${ }^{1}{ }^{*} \bullet$ Aurélien François ${ }^{2}$ \\ ${ }^{1}$ Manchester Metropolitan University, Faculty of Business and Law, Manchester, UK \\ ${ }^{2}$ University of Rouen, Laboratoire Cetaps, Mont Saint Aignan, France
}

Received: 10 July 2020

Revised: 2 November 2020

Accepted: 18 December 2020

\begin{abstract}
Does a country's income inequality affect its citizens' quest for equality in leisure? To answer this question, the letter investigates the impact of competitive balance on fan demand (stadium attendance) in European men's football over the 2006-18 period, splitting leagues into groups depending on their country's income inequality. Competitive balance has a significant negative impact on stadium attendance in countries with lowest income inequality and a significant positive impact in countries with highest income inequality and the whole sample. Findings suggest that, in leisure, European football fans look for the (in)equality their national economy does not offer.
\end{abstract}

Keywords: income inequality; quest for equality; competitive balance; stadium attendance; European men's football

JEL Classification Codes: Z20, L83, C50

\section{Introduction}

Income inequality is a key topic in the economic field having received and still receiving a lot of attention in academia, see e.g. the Special Issue 'Inequality and the Great Recession' edited by Esposito (2014) in the journal or, more recently, the letter by Özdemir (2019). To the best of the authors' knowledge, a question remains unexplored: does a country's income inequality affect its citizens' quest for equality in leisure? To answer this question, this letter investigates how the demand for European men's football is impacted by the level of sporting equality, depending on a country's income inequality. Sporting equality is measured through competitive balance, a concept well established in the sports economics literature (see e.g. Scelles et al., 2020). Simply put, it postulates the necessity of sporting equilibrium between playing strengths to generate outcome uncertainty and thus fan demand, justifying the existence of redistribution mechanisms such as revenue sharing (Szymanski, 2003). UEFA (Union of European Football Associations) President Aleksander Ceferin considers that competitive balance is currently the main challenge in European football, both at continental and national levels (UEFA, 2019). Its impact on fan demand can be established by looking at television audience (Humphreys \& Pérez, 2019; Pérez et al., 2017) and stadium attendance (García \& Rodríguez, 2002). This letter

\footnotetext{
${ }^{*}$ Corresponding author. E-mail: N.Scelles@mmu.ac.uk.
}

Citation: Scelles, N., and François, A. (2021) Does a country's income inequality affect its citizens' quest for equality in leisure? Evidence from European men's football, Economics and Business Letters, 10(2), 133-139.

DOI: $10.17811 / \mathrm{ebl} \cdot 10.2 .2021 .133-139$ 
focuses on the latter. As noted recently by Valenti et al. (2020, p. 510): "The sports economics literature has produced substantive amounts of empirical research on stadium attendance for professional team sports". Such studies usually look at one or a few competitions. Valenti et al. (2020) highlight that conflicting results have been found about the impact of competitive balance on fan demand.

In this letter, the aim is to investigate the determinants of stadium attendance in European men's football first tiers over the 2006-18 period (54 first tiers over 12 seasons), with a specific focus on the impact of competitive balance. In particular, we want to examine whether the levels of income inequality in the different European countries affect the impact of competitive balance on stadium attendance in the men's football first tiers in these countries. In other words, do fans in countries with lower (higher) income inequality value more (less) competitive balance as a consequence of equality being (not) valued in such countries? Or, on the contrary, do fans in countries with higher (lower) income inequality value more (less) competitive balance, looking for the (in)equality in football they do not find in their national economy?

\section{Methods}

An econometric model was established to test the impact of competitive balance on stadium attendance in European men's football. Stadium attendance is measured at league (country) level as the average of the attendances per game for a given season. Its key determinant is the identities of the teams competing in a given season. In European men's football first tiers, the teams are not exactly the same from one season to another. Indeed, the teams ending in the lowest positions in the league table are replaced the next season by those ending in the highest positions in the second tiers through a system of sporting promotions and relegations. Teams that are promoted have not necessary the same potential in terms of stadium attendance as the teams that are relegated.

Beyond sporting relegations, teams can also be relegated for administrative reasons due to events such as corruption scandals (e.g. Juventus Turin in Italy in 2006) or insolvencies (e.g. Glasgow Rangers in Scotland in 2012). Such relegations can also impact the average stadium attendance in the league. For example, in the Scottish first tier, Glasgow Rangers did not take part from 2012 to 2016, having been relegated from the first to the fourth tier in 2012. Average stadium attendance in the Scottish first tier went down from 14,685 spectators in 2011-12 to 11,073 in 2012-13 and decreased even further the following seasons before increasing to 13,604 in 2016-17, when Glasgow Rangers regained access to the league.

The influence of the teams taking part on average stadium attendance in a league a given season suggests the need to control for such influence. In this letter, we use the mean of the average stadium attendances in the first tier over the 2006-18 period for the teams taking part in the league a given season. For example, in 2017-18 in the French Ligue 1, Caen took part. Its average in the division over the 2006-18 was 17,308 spectators so this data was used for this club in the calculation of the mean of the average stadium attendances in the first tier over the 2006-18 period for the teams taking part in the league in 2017-18. By operating in the same way for the other clubs taking part in 2017-18, the mean of the average stadium attendances in the first tier over the 2006-18 period for the teams taking part in the league in 2017-18 was calculated. Because some teams had a new or renovated stadium over the period studied and this influenced their stadium attendance, we calculated their average stadium attendance before and after the new or renovated stadium and used the relevant data in our calculations. The mean of the average stadium attendances is used as a baseline against which assessing the impact of competitive balance on stadium attendance. To prevent endogeneity issues between stadium attendance as dependent variable and the mean of the average stadium attendances as independent variable, the dependent variable is (stadium attendance - mean of the average stadium attendances), named 'Attendance Difference' afterwards. 
For competitive balance, there is a need for a measure controlling for the specific way points are allocated in the sporting tables of European men's football first tiers. In European men's football, a win equals three points, a draw one point and a loss zero point. The usual measures of competitive balance at the end of a season assume that a draw equals half a win, which is not accurate in European men's football. Avila-Cano and Triguero-Ruiz (2018) have developed a measure derived from Owen et al. (2007) and adapted to leagues with three-points win: the normalised Hirschman-Herfindahl index $\mathrm{HHI}_{\text {norm }}$ :

$$
\mathrm{HHI}_{\text {norm }}=\left(\mathrm{HHI}-\mathrm{HHI}_{\text {min }}\right) /\left(\mathrm{HHI}_{\max }-\mathrm{HHI}_{\text {min }}\right)
$$

$\mathrm{HHI}$ is the sum of the squares of the market shares (shares of points) captured by each club:

$$
\mathrm{HHI}=\Sigma\left(\mathrm{p}_{\mathrm{i}} / \Sigma \mathrm{p}\right)^{2}
$$

where $\mathrm{p}_{\mathrm{i}}$ corresponds to the points captured by club $\mathrm{i} ; \mathrm{i}=1,2 \ldots, \mathrm{N}$, with $\mathrm{N}$ corresponding to the number of clubs in the league over the season; and $\Sigma$ p corresponds to the sum of the $\mathrm{N}$ clubs' points.

$\mathrm{HHI}_{\min }$ is the lower-bound value of $\mathrm{HHI}$ and corresponds to perfect balance in terms of shares of points. Its value depends on the number of clubs in the league:

$$
\mathrm{HHI}_{\text {min }}=1 / \mathrm{N}
$$

$\mathrm{HHI}_{\text {max }}$ is the upper-bound value of $\mathrm{HHI}$ and corresponds to the most unequal distribution in terms of shares of points. Its value depends on the number of clubs in the league too but also $\mathrm{q}^{*}$, the number of teams that won all matches except for those played against teams preceding them in the table, whereas the $\left(\mathrm{N}-\mathrm{q}^{*}\right)$ other teams tied all matches:

$$
\begin{aligned}
& \mathrm{HHI}_{\max }=\left[2\left(\mathrm{q}^{*}\right)^{3}+(-6 \mathrm{~N}+5 / 2)\left(\mathrm{q}^{*}\right)^{2}+(6 \mathrm{~N} 2-5 \mathrm{~N}+1 / 2) \mathrm{q}^{*}+\right. \\
& \mathrm{N}(\mathrm{N}-1) 2] /\left[\left(-\left(\mathrm{q}^{*}\right)^{2}-(1-2 \mathrm{~N}) \mathrm{q}^{*}+2 \mathrm{~N}(\mathrm{~N}-1)\right) / 2\right]^{2}
\end{aligned}
$$

with $\mathrm{q}^{*}$ such as:

$$
\begin{aligned}
& 0>-(1 / 2) q^{5}+((5 / 2) N-9 / 4) q^{4}+\left(-8 N^{2}+12 N-7 / 2\right) q^{3}+ \\
& \left(11 N^{3}-27 N^{2}+18 N-9 / 4\right) q^{2}+\left(8 N^{4}-6 N^{3}-9 N^{2}+(15 / 2) N-1 /\right. \\
& 2) q-4 N^{5}+12 N^{4}-13 N^{3}+6 N^{2}-N
\end{aligned}
$$

Triguero-Ruiz and Avila-Cano (2019) have established the Distance to Competitive Balance (DCB) - a mathematical distance fulfilling the cardinality property and, as such, preserving the proportions - as the square root of $\mathrm{HHI}_{\text {norm }}$ :

$$
\mathrm{DCB}=\sqrt{\mathrm{HHI}_{\text {norm }}}
$$

In the present research, DCB is used. A higher value means a higher inequality, i.e. a positive impact of competitive balance on stadium attendance would be associated with a negative sign.

A league may have a higher average attendance if the teams with the highest potential attendance perform well. To test this idea, the correlation coefficient between such potential attendance (the mean of the average stadium attendances) for a team and its number of points gained over a season is calculated for each league season used, named 'Correlation Potential Points' afterwards.

A league attendance may also be affected by the economic situation in the country, especially over the period studied with the European debt crisis having started in 2009. 'Employment Rate Difference' is used, calculated as the difference between the employment rate for the year under investigation and the mean of the employment rates over the period studied for the country analysed. Data shows that overall the situation improved towards the end of the period, yet crises may have a long lasting effect on consumption behaviours. As an alternative to Employment Rate Difference, a dummy 'European Debt Crisis' is also used, taking the value 1 from 2009. 
Based on the variables described above, the following equation is estimated in this study:

$$
\begin{aligned}
& \text { Attendance Difference }{ }_{i t}=\beta_{0}+\beta_{1} * D C B_{i t}+\beta_{2} * \\
& \text { Correlation Potential Points it }+\beta_{3} * \\
& \text { Employment Rate Difference (or European Debt Crisis) }{ }_{i t}+\tau_{\mathrm{t}}+\mu_{\mathrm{i}}+\varepsilon_{i t}
\end{aligned}
$$

where the variables are for league $\mathrm{i}$ in season $\mathrm{t}$. The yearly effects are represented by $\tau$. To control for unobserved heterogeneity across countries, $\mu$ is inputted.

\section{Data}

Data come from European Football Statistics for stadium attendance, Soccerway for competitive balance, both sources for Correlation Potential Points and the World Bank for employment rates. The impact of the independent variables on stadium attendance was tested for all European countries, as well as for different groups depending on the countries' income inequality as measured by Frederick Solt (https://fsolt.org/swiid/). Indeed, to answer our research question, countries in our sample were split into four groups: income inequality below 26.4, between 26.4 and 30.85, between 30.85 and 35.3, and exceeding 35.3 (mean $=30.86$ and

\begin{tabular}{|c|c|c|c|c|c|}
\hline & $\begin{array}{c}\text { All } \\
\text { countries }\end{array}$ & $\begin{array}{c}\text { Income } \\
\text { inequality below } \\
26.4 \\
\end{array}$ & $\begin{array}{c}\text { Income } \\
\text { inequality 26.4- } \\
30.85 \\
\end{array}$ & $\begin{array}{c}\text { Income inequality } \\
30.85-35.3\end{array}$ & $\begin{array}{c}\text { Income } \\
\text { inequality } \\
\text { above } 35.3 \\
\end{array}$ \\
\hline $\begin{array}{c}\text { Absolute } \\
\text { Attendance } \\
\text { Difference }\end{array}$ & $\begin{array}{l}422.46 \\
(556.48)\end{array}$ & 339.86 (328.46) & $467.63(707.78)$ & $452.10(522.71)$ & $\begin{array}{l}394.12 \\
(604.84)\end{array}$ \\
\hline$D C B$ & $\begin{array}{c}0.47 \\
(0.10) \\
\end{array}$ & $\begin{array}{c}0.43 \\
(0.08) \\
\end{array}$ & $\begin{array}{c}0.46 \\
(0.09) \\
\end{array}$ & $\begin{array}{c}0.50 \\
(0.10) \\
\end{array}$ & $\begin{array}{c}0.48 \\
(0.11) \\
\end{array}$ \\
\hline $\begin{array}{c}\text { Correlation } \\
\text { Potential } \\
\text { Points } \\
\end{array}$ & $\begin{array}{c}0.56 \\
(0.24)\end{array}$ & $\begin{array}{c}0.47 \\
(0.26)\end{array}$ & $\begin{array}{c}0.60 \\
(0.18)\end{array}$ & $\begin{array}{c}0.60 \\
(0.24)\end{array}$ & $\begin{array}{c}0.55 \\
(0.22)\end{array}$ \\
\hline $\begin{array}{c}\text { Absolute } \\
\text { Employment } \\
\text { Rate } \\
\text { Difference }\end{array}$ & $\begin{array}{c}1.70 \% \\
(1.54 \%)\end{array}$ & $\begin{array}{c}1.82 \% \\
(1.87 \%)\end{array}$ & $\begin{array}{l}1.52 \% \\
(1.34 \%)\end{array}$ & $\begin{array}{l}1.66 \% \\
(1.48 \%)\end{array}$ & $\begin{array}{c}1.97 \% \\
(1.35 \%)\end{array}$ \\
\hline Observations & 543 & 126 & 143 & 202 & 72 \\
\hline Groups & 48 & 13 & 15 & 20 & 10 \\
\hline Countries & & $\begin{array}{c}\text { Azerbaijan, } \\
\text { Belarus, Belgium, } \\
\text { Croatia (2006- } \\
\text { 2007), Czech } \\
\text { Republic, } \\
\text { Denmark (2006- } \\
\text { 2014), Finland, } \\
\text { Iceland (2010- } \\
\text { 2017), } \\
\text { Kazakhstan } \\
\text { (2010-2017), } \\
\text { Norway, } \\
\text { Slovakia, } \\
\text { Slovenia, Sweden }\end{array}$ & $\begin{array}{l}\text { Austria, Croatia } \\
\text { (2008-2017), } \\
\text { Cyprus, Denmark } \\
\text { (2015-2017), } \\
\text { France, Germany, } \\
\text { Hungary, Iceland } \\
\text { (2006-2009), } \\
\text { Ireland, } \\
\text { Kazakhstan } \\
\text { (2006-2009), } \\
\text { Luxembourg, } \\
\text { Netherlands, } \\
\text { Poland (2015- } \\
\text { 2017), } \\
\text { Switzerland, } \\
\text { Ukraine }\end{array}$ & $\begin{array}{l}\text { Bulgaria, England, } \\
\text { Estonia, Greece, } \\
\text { Italy, Israel (2016- } \\
\text { 2017), Latvia } \\
\text { (2014-2017), } \\
\text { Lithuania (2006- } \\
\text { 2016), Macedonia, } \\
\text { Moldova (2012-- } \\
\text { 2017), Montenegro, } \\
\text { Northern Ireland, } \\
\text { Poland (2006- } \\
\text { 2014), Portugal, } \\
\text { Romania, Russia } \\
\text { (2010 and 2012- } \\
\text { 2017), Scotland, } \\
\text { Serbia, Spain, } \\
\text { Wales }\end{array}$ & $\begin{array}{c} \\
\text { Albania, } \\
\text { Armenia, } \\
\text { Bosnia- } \\
\text { Herzegovina, } \\
\text { Georgia, Israel } \\
\text { (2006-2015), } \\
\text { Latvia (2006- } \\
\text { 2016), Lithuania } \\
\text { (2017), } \\
\text { Moldova (2006- } \\
\text { 2011), Russia } \\
\text { (2006-2009 and } \\
\text { 2011), Turkey }\end{array}$ \\
\hline
\end{tabular}
standard deviation $=4.48$ for income inequality). Table 1 provides the descriptive statistics.

Table 1. Descriptive statistics, European men's football, 2006-18.

Notes: Mean provided first then standard deviation (in brackets). 


\section{Results}

Tables 2 (with Employment Rate Difference) and 3 (with European Debt Crisis) provide the results. All regressions are robust random effects after the Hausman tests provided Prob>chi2 above 0.05 , then the xtreghet command on Stata unveiled heteroscedasticity. Bootstrapping with 1,000 replications was applied for regressions 2, 3 and 5. Table 2 shows a significant positive impact of competitive balance, the correlation between potential attendance and points, and employment rate on stadium attendance in the whole sample. Results in Table 2 are less convincing when splitting countries depending on their income inequality. However, when replacing Employment Rate Difference by European Debt Crisis (Table 3), competitive balance has a significant negative impact in the countries with the lowest income inequality (at the 10\% level before applying bootstrapping, $\mathrm{p}=0.102$ when applying it), and a significant positive impact in countries with the highest income inequality.

Table 2. Results for Attendance Difference equation with Employment Rate Difference, European men's football, 2006-18.

\begin{tabular}{cccccc}
\hline \hline & All countries & $\begin{array}{c}\text { Income } \\
\text { inequality below } \\
\mathbf{2 6 . 4}\end{array}$ & $\begin{array}{c}\text { Income } \\
\text { inequality 26.4- } \\
\mathbf{3 0 . 8 5}\end{array}$ & $\begin{array}{c}\text { Income } \\
\text { inequality 30.85- } \\
\mathbf{3 5 . 3}\end{array}$ & $\begin{array}{c}\text { Income } \\
\text { inequality } \\
\text { above 35.3 }\end{array}$ \\
\hline \hline DCB & $-515.00^{*}$ & 367.36 & $-1,349.26$ & 172.12 & $-1,276.25$ \\
$(286.42)$ & $(274.60)$ & $(911.10)$ & $(240.77)$ & -21.57 \\
\hline $\begin{array}{c}\text { Correlation } \\
\text { Potential }\end{array}$ & $257.72 * *$ & 221.78 & $536.72)$ \\
Points & $(124.20)$ & $(143.86)$ & $(603.72)$ & $(210.98)$ & $(277.86)$ \\
\hline Employment & $44.63 *$ & 45.00 & 74.16 & 46.50 & -21.89 \\
Rate Difference & $(26.17)$ & $(39.28)$ & $(73.51)$ & $(52.94)$ & $(29.20)$ \\
\hline Constant & 98.55 & -227.42 & 290.43 & $-339.46 *$ & 698.36 \\
& $(105.28)$ & $(147.18)$ & $(265.90)$ & $(204.80)$ & $(493.62)$ \\
\hline Observations & 543 & 126 & 143 & 202 & 72 \\
\hline Groups & 48 & 13 & 15 & 20 & 10 \\
\hline $\mathrm{R}^{2}$ within & 0.0386 & 0.0772 & 0.0635 & 0.0383 & 0.0372 \\
\hline $\mathrm{R}^{2}$ between & 0.0514 & 0.2916 & 0.3539 & 0.0353 & 0.2110 \\
\hline $\mathrm{R}^{2}$ overall & 0.0338 & 0.0824 & 0.0714 & 0.0361 & 0.0392 \\
\hline \hline
\end{tabular}

Notes: ${ }^{*} \mathrm{p}<0.1 ; * * \mathrm{p}<0.05$. Standard errors displayed in brackets.

Table 3. Results for Attendance Difference equation with European Debt Crisis, European men's football, 2006-18.

\begin{tabular}{|c|c|c|c|c|c|}
\hline & All countries & $\begin{array}{c}\text { Income } \\
\text { inequality } \\
\text { below } 26.4 \\
\end{array}$ & $\begin{array}{c}\text { Income } \\
\text { inequality 26.4- } \\
30.85 \\
\end{array}$ & $\begin{array}{c}\text { Income } \\
\text { inequality } \\
30.85-35.3 \\
\end{array}$ & $\begin{array}{c}\text { Income } \\
\text { inequality } \\
\text { above } 35.3 \\
\end{array}$ \\
\hline$D C B$ & $\begin{array}{l}-485.18 * \\
(280.39) \\
\end{array}$ & $\begin{array}{c}389.70 \\
(238.22) \\
\end{array}$ & $\begin{array}{c}-1,815.62 \\
(1,197.63) \\
\end{array}$ & $\begin{array}{c}74.28 \\
(225.03) \\
\end{array}$ & $\begin{array}{c}-1,026.69^{*} \\
(618.76) \\
\end{array}$ \\
\hline $\begin{array}{c}\text { Correlation } \\
\text { Potential Points }\end{array}$ & $\begin{array}{l}220.39 * \\
(117.58)\end{array}$ & $\begin{array}{c}195.92 \\
(135.27)\end{array}$ & $\begin{array}{c}700.44 \\
(677.90)\end{array}$ & $\begin{array}{c}246.91 \\
(181.82)\end{array}$ & $\begin{array}{c}54.37 \\
(214.03)\end{array}$ \\
\hline $\begin{array}{c}\text { European Debt } \\
\text { Crisis }\end{array}$ & $\begin{array}{c}-333.78 * * * \\
(93.34)\end{array}$ & $\begin{array}{c}-447.71 * * * \\
(149.78) \\
\end{array}$ & $\begin{array}{c}-13.29 \\
(181.08) \\
\end{array}$ & $\begin{array}{c}-416.29 * * * \\
(150.80)\end{array}$ & $\begin{array}{c}-490.08 * * \\
(233.75) \\
\end{array}$ \\
\hline Constant & $\begin{array}{c}368.18 * * * \\
(116.85)\end{array}$ & $\begin{array}{c}142.83 \\
(207.46) \\
\end{array}$ & $\begin{array}{r}428.66 \\
(290.45) \\
\end{array}$ & $\begin{array}{c}97.43 \\
(202.61) \\
\end{array}$ & $\begin{array}{l}932.41 * * \\
(475.98)\end{array}$ \\
\hline Observations & 563 & 135 & 143 & 203 & 73 \\
\hline Groups & 49 & 13 & 15 & 20 & 10 \\
\hline $\mathrm{R}^{2}$ within & 0.0580 & 0.2080 & 0.0456 & 0.0775 & 0.0748 \\
\hline $\mathrm{R}^{2}$ between & 0.0192 & 0.4217 & 0.0779 & 0.0623 & 0.7202 \\
\hline $\mathrm{R}^{2}$ overall & 0.0523 & 0.2123 & 0.0417 & 0.0744 & 0.1057 \\
\hline
\end{tabular}

Notes: $* \mathrm{p}<0.1 ; * * \mathrm{p}<0.05 ; * * * \mathrm{p}<0.01$. Standard errors displayed in brackets. 


\section{Concluding remarks}

The letter confirms that a country's income inequality affects its citizens' quest for equality in leisure. Based on the case of European men's football over the 2006-18 period, it shows that fans in the countries with highest income inequality value sporting equality (competitive balance), while fans in the countries with lowest income inequality value sporting inequality instead. Our findings suggest that, in leisure, European football fans look for the (in)equality their national economy does not offer. When deciding about revenue sharing schemes between clubs, national football leagues and governments (where such schemes are decided by governmental law) should have this information in mind, although stadium attendance does not represent the whole fan demand (e.g. TV audience), and the sustainability of football in a country may require a certain level of financial solidarity between clubs, independently of fans' preferences.

Our findings also confirm that the European football body UEFA is right in identifying competitive balance as a main challenge. Indeed, we find a significant positive impact of competitive balance on stadium attendance for the whole sample. UEFA can hardly differentiate its decisions across countries based on the different impacts from one group of countries to another, as identified in this letter. As such, its position to promote competitive balance for European (men's) football as a whole is understandable and supported by our results.

A limitation of our findings is the low number of observations when splitting into groups. Directions for future research are the extension of the period studied in European men's football, the application of similar studies to other continents for men's football, to women's football, other professional team sports and other leisure activities, as well as measuring fan demand through TV audience, although data availability across countries might be a challenge for the latter.

\section{Acknowledgements}

The authors would like to thank the Editor-in-Chief and the two anonymous reviewers for their feedback on the letter. All errors are the authors' own.

\section{References}

Avila-Cano, A., and Triguero-Ruiz, F. (2018) The distribution of soccer leagues scores that generates the minimum of competitive balance: Truncated-cascade distribution, Technical Report No. 2018-04. Department of Economic Theory, Malaga Economic Theory Research Center, Universidad de Malaga, Malaga, Spain, available at http://webdeptos.uma.es/THEconomica/malagawpseries/Papers/METCwp2018-4.pdf

Esposito, L. (Ed.) (2014) Special issue inequality and the great recession, Economics and Business Letters, 3(3), 134-136.

García, J., and Rodríguez, P. (2002) The determinants of football match attendance revisited: Empirical evidence from the Spanish football league, Journal of Sports Economics, 3(1), 18 38.

Humphreys, B., and Pérez, L. (2019) Loss aversion, upset preference, and sports television viewing audience size, Journal of Behavioral and Experimental Economics, 78, 61-67.

Owen, P. D., Ryan, M., and Weatherston, C.R. (2007) Measuring competitive balance in professional team sports using the Herfindahl-Hirschman index, Review of Industrial Organization, 31(4), 289-302.

Özdemir, O. (2019) Rethinking the financial Kuznets curve in the framework of income inequality: Empirical evidence on advanced and developing economies, Economics and Business Letters, 8(4), 176-190.

Pérez, L., Puente, V., and Rodríguez, P. (2017) Factors determining TV soccer viewing: Does uncertainty of outcome matter?, International Journal of Sport Finance, 12(2), 124-139. 
Scelles, N., François, A., and Dermit-Richard, N. (2020). Determinants of competitive balance across countries: Insights from European men's football first tiers, 2006-2018, Managing Sport and Leisure, doi: 10.1080/23750472.2020.1784036.

Szymanski, S. (2003) The economic design of sporting contests, Journal of Economic Literature, 41(4), 1137-1187.

Triguero-Ruiz, F., and Avila-Cano, A. (2019).The distance to competitive balance: A cardinal measure, Applied Economics, 51(7), 698-710.

UEFA (2019) The European club footballing landscape: Club licensing benchmarking report financial year 2017, available at https://www.uefa.com/MultimediaFiles/Download/ OfficialDocument/uefaorg/Clublicensing/02/59/40/27/2594027_DOWNLOAD.pdf

Valenti, M., Scelles, N., and Morrow, S. (2020). The determinants of stadium attendance in elite women's football: Evidence from the UEFA Women's Champions League, Sport Management Review, 22(3), 509-520. 